\title{
Cross-Border Mergers and Acquisitions Factors in Joining the European Union Countries
}

\author{
Daiva Burksaitiene $^{1}$, Kristina Garskaite-Milvydiene ${ }^{2}$ \\ Faculty of Business Management, Vilnius Gediminas Technical University, \\ Vilnius, Lithuania \\ E-mails: ${ }^{1}$ daiva.burksaitiene@vgtu.lt (corresponding author); ${ }^{2}$ kristina.garskaite@vgtu.lt
}

Received 26 February 2017; accepted 05 April 2017

\begin{abstract}
Mergers and acquisitions (M\&As) are increasingly being used in the business world, and this process plays an important role in economic theory and lays the foundations for sustainable business development. The global recovery in foreign direct investment (FDI) was strong in 2015, with global FDI flows jumping by $38 \%$, their highest level since the global economic and financial crisis of 2008-2009. A surge in cross-border M\&As to \$721 billion, from $\$ 432$ billion in 2014, was the principal factor behind the global rebound. These M\&As were partly driven by very large corporate reconfigurations by multinational enterprises (MNEs), i.e. changes in legal or ownership structures, including shifting their headquarters for strategic reasons and tax inversions. This paper examines the key M\&As stimulating strategic objectives and causes, and ways of this process, as well as the cross-border M\&As market activity. The objective of this paper is to identify ways, purposes and reasons of M\&As transactions, and to present the factors influencing this process and market activity. The object of this research is the M\&As transactions market. Research methodology of this paper is based on scientific literature and statistical information systematic, comparative, logical and econometric analysis.
\end{abstract}

Keywords: M\&As factors, synergy, cross-border M\&As, GDP growth, correlation analysis.

JEL Classification: G34, M21.

Conference topic: Contemporary Financial Management.

\section{Introduction}

Mergers and acquisitions (M\&As) of enterprises are becoming increasingly frequent, as the business environment is complex and changing. M\&As are increasingly being used in the business world by enterprises to take strategic positions. Smaller enterprises, which are incapable of competing in the international market, are forced to bring themselves under the protection of large international enterprises. An enterprise using strategic planning to ensure its survival are continually confronted with the problem of whether to promote the growth externally or grow using internal resources (Campbell et al. 2008; Roman, Rusu 2011; Kotane, Kuzmina-Merlino 2012). External expansion is related to business mergers. The debate on this issue is an ongoing process.

Many enterprises merge in order to expand their activities and to diversify the risks of such activities. It is also highly important to evaluate the strategic and organisational competencies of the enterprises undergoing a merger. By acquiring the strategic and organisational competencies at the time of the merger, it is possible to ensure the company's growth and gain a competitive advantage, boost low productivity, increase turnover and profitability, and improve management efficiency (Lin et al. 2006; DePamphilis 2010; Gaughan 2015).

There exist various reasons for which enterprises merge or acquire one another. Corporate M\&As are generally more frequent under good economic conditions in the hope of a future which is at least not worse, if not better, than the current situation. It is expected that corporate M\&As may help to capture new technological opportunities, to enhance an enterprise's trademark, to achieve a variety of synergistic effects, economies of scale and management, improved allocation of resources, and growth of market power, and to attain a number of other goals (Cornett et al. 2006; Parikh 2011). Nevertheless, in aiming at a successful completion of the merger or acquisition process it is necessary to assess a number of key aspects and prepare for possible surprises as early as at the beginning of the process.

While the number of strategic M\&As worldwide continues to grow, the experience of this process shows that this growth strategy may be not only successful, but also unsuccessful: merged enterprises fail to gain the expected benefits, business value and profitability fall, skilled workers are lost. However, researchers and practitioners alike

(C) 2017 D. Burksaitiene, K. Garskaite-Milvydiene. Published by VGTU Press. This is an open-access article distributed under the terms of the Creative Commons Attribution (CC BY 4.0) License, which permits unrestricted use, distribution, and reproduction in any medium, provided the original author and source are credited. 
claim that M\&As nonetheless bring financial benefits. For the enterprises which are active in M\&As markets, such transactions may ensure a lasting success, whereas for the individuals successfully managing this process it may become one of the most important moments spanning their entire career.

The topic of M\&As is becoming the subject of studies in the continuously growing circle of researchers in different fields around the world. Recently, the volume of global investments focused on the implementation of merger processes has increased significantly (Gruodis 2009; Bevins et al. 2010). The practical significance of mergers both from the strategic and monetary perspectives has increased. The authors in different scientific fields who have researched on reasons for mergers have, within the limits of their scientific interests, provided very different interpretations of the mergers and their impact on the further activities of an enterprise. Some financial professionals, when considering the processes of corporate mergers, have focused on the shareholder value being acquired (Cornett et al. 2006). An analysis of other studies has found that mergers do not always promote increase in an enterprise's value, taking account of both short- and long-term indicators of the enterprise (Fraser, Zhang 2009; Agrawal, Knoeber 2012), while some authors have argued that mergers may even reduce the value of the enterprise subject to acquisition and affect the volatility of the profit earned (Chatterjee 2007; Campbell et al. 2008).

The objective of this paper is to identify ways, purposes and reasons of M\&As transactions, and to present the factors influencing this process and market activity special attention paying for cross-border M\&As factors.

The object of the research is the M\&As transactions market.

Research methodology is based on scientific literature and statistical information systematic comparative, logical and econometric analysis.

\section{Methods, goals and reasons for mergers and acquisitions (M\&As) of enterprises}

In searching for possibilities and ways to increase an enterprise's business value, the restructuring of enterprises can be implemented through mergers or acquisitions of such enterprises (DePamphilis 2010; Adam, Jacob 2012; Gaughan 2015; Garskaite-Milvydiene, Burksaitiene 2016). Therefore, depending on the methods of business restructuring some of them may include (Cornett et al. 2006; Neary 2007; Baraz, Sakar 2011; Deng et al. 2013):

- Mergers - a transaction by which a completely new enterprise is created, while former enterprises are joined into a new element. Mergers can be described as all the cases when two entities are mutually integrated to form a new organisational structure;

- Acquisitions - a transaction by which one enterprise or natural person acquires another business. Such an acquisition is usually financed by cash or a certain debt instrument (e. g. by issuing bonds). Acquisitions can be defined as the situations when another business or a controlling interest in another enterprise is acquired, but both entities continue to exist.

The Law of the Republic of Lithuania on Companies (Lietuvos Respublikos akcinių bendrovių istatymas [Law of the Republic of Lithuania on Companies] 1994) provides that companies may merge in the following ways:

1) by way of merger by acquisition, when a company resulting from the reorganisation acquires other (one or more) companies which cease to exist as legal persons;

2) by the formation of a new company from the companies which cease to exist as legal persons.

In order to identify the strategic goals of M\&As, possible types of mergers should be distinguished, as they determine the key goals pursued by executives of enterprises and search for opportunities (Cullen, Praveen 2011; Burkart et al. 2012; MacNab, Worthley 2013; Milichovsky, Simberova 2015).

Three types of M\&As are usually distinguished (Ginevičius et al. 2005; Neary 2007; Lin et al. 2006, 2008; DePamphilis 2010; Brigham, Daves 2012; Gaughan 2015):

- Horizontal - mergers of competing enterprises in the same industry. A horizontal merger is a union of the enterprises engaged in similar competing activities and producing the same product, that is, purchase of another enterprise in the same industry. Such an acquisition aims at achieving the economies of scale in production and distribution, as well as a greater weight on the market. It is also possible to distinguish a similar - concentric - type, when the enterprises linked by similar production processes, technologies or product lines are purchased. Upon completing the acquisition, it is expected to take advantage of shared resources and shared distribution channels and enter the market for the product concerned;

- Vertical - mergers of the enterprises linked by certain relationships, for example, the purchasing enterprise is the supplier or purchaser (customer) of the product of the enterprise being purchased. A vertical merger is a union of the enterprises in different areas of activity which are characterised by direct technological and commercial links. This type of mergers means that an enterprise is joined with one of its suppliers which limits competition and there exists a strong customer-supplier relationship. Vertical integration is generally used when the intermediate product market is imperfect, for example, due to scarcity of resources, or in order to control the specifications of the intermediate product;

- Conglomerate - mergers of the enterprises operating in completely different areas. A conglomerate merger is a union of enterprises in different industries which are not interrelated technologically, that is, which 
manufacture the products directly independent of each other. In this case, the purchasing enterprise expects to increase its stability and balance the enterprise's income portfolio by acquiring an enterprise in an unrelated industry.

In considering the potential of enterprises to create added value through a merger, not only the type of a corporate merger, but also such aspects as the degree of relatedness of the enterprises or the nature of acquisition of an enterprise are often analysed as an important factor. In the case of a merger of similar enterprises, additional business value may be created by acquiring market power and achieving economies of scale. Potential efficiency gains in respect of a merger of different businesses are more general in nature. Such gains may be determined by reduced financing costs due to an increase in risk diversification, achieved administrative efficiency, acquired human capital of higher qualifications, and, as a result of corporate growth, an increase in market power (Lin et al. 2006; Chatteqee 2007; Hennephof 2009). Thus, to merge or to acquire an operating business is less risky and there is no need to wait for it to give tangible results, investments are safer - there are more advantages, although there are also disadvantages (Table 1). However, when purchasing an existing business it is important to not overestimate it, to assess threats, and to provide that finding a business suitable for a merger or an acquisition is not easy and requires time.

Table 1. Advantages and disadvantages of M\&As of enterprises (Source: Lin et al. 2006; Chatteqee 2007; Ficery et al. 2007; Wang, Xie 2009; Agrawal, Knoeber 2012; Brigham, Daves 2012; MacNab, Worthley 2013; Gaughan 2015)

\begin{tabular}{l|l}
\hline \multicolumn{1}{c|}{ Advantages of M\&As of enterprises } & \multicolumn{1}{c}{ Disadvantages of M\&As of enterprises } \\
\hline $\begin{array}{l}\text { Since an enterprise is already in operation, it would be easier to } \\
\text { obtain financing for the development of business and expansion of } \\
\text { activities; }\end{array}$ & $\begin{array}{l}\text { M\&As of enterprises may require considerable invest- } \\
\text { ments, including the price of a business being acquired, } \\
\text { the costs of the studies carried out; } \\
\text { The enterprise's products or services offered in the market are } \\
\text { known, it is possible to increase the enterprise's capacities; } \\
\text { difficulties related to the enterprise's management, organi- } \\
\text { sational structure, the need for additional business financ- } \\
\text { possible to expand the market; }\end{array}$ \\
$\begin{array}{l}\text { It is possible to take advantage of shared resources, common distri- } \\
\text { bution channels, enter the market for the product concerned; } \\
\text { suppliers. }\end{array}$ \\
$\begin{array}{l}\text { Economies of scale and other synergistic effects are achieved; } \\
\text { Human resources are qualified, it is possible to change or expect a } \\
\text { more efficient management. }\end{array}$
\end{tabular}

Economic theory provides a number of possible reasons for corporate M\&As, and it is difficult to single out one specific reason for these processes taking place in the market, however the following could be referred to as the key and most common reasons (Ficery et al. 2007, Roman, Rusu 2011; Ulrich 2012a, 2012b; MacNab, Worthley 2013; Gaughan 2015): efficiency-related reasons are often based on economies of scale or other synergistic effects; the willingness to expand and increase an enterprise's capacities; attempts to increase power and improve market position, reduce competition; the aspiration to benefit from the opportunities offered by diversification in the management of corporate risks; the aim to remove incompetent executives of the enterprises being acquired.

Researchers and practitioners usually distinguish certain strategic goals of an enterprise which promote search for and analysis of opportunities in respect of M\&As (Ficery et al. 2007; Hennephof 2009; Novickytė, Šileika 2010; Parikh 2011; Stankeviciene et al. 2014):

- Consolidation of the market in a given geographical area, that is, horizontal mergers take place, with the main goal being acquisition of competitors in the same market, thus gaining greater market power, possibly even a monopoly, unless there exist sufficient legal levers;

- Acquisition of new products, services, or technologies or continuation of their development. By entering into a horizontal merger and implementing this strategy, enterprises aim at increasing their competitiveness in the market through the acquisition of new products, services or technologies and gaining of access to additional distribution channels;

- Entry into a new geographic market. These horizontal mergers take place when one or more enterprises perceive new strategic opportunities in expanding into new markets and thus increasing their profitability. The acquisition of an enterprise already having access to that market may bring synergistic benefit, and the extent of such benefit will depend on how much cheaper and faster it would be possible to enter the market;

- Vertical integration. This strategy aims at entering supply or product distribution channels, thus providing a wider range of opportunities to regulate business. Vertical integration requires very little organisational consolidation and standardisation, however, it requires a high level of coordination, as enterprises linked by certain relationships are merged;

- Entry into a new business sector. The aim of this strategy is, through the acquisition of an enterprise sharply contrasting with the acquirer's business structure, to undertake new activities by expanding the acquirer's range of services, products, and available technology. This strategy constitutes a basis for conglomerate M\&As. 
There are several ways in which M\&As can enhance efficiency and overall benefits for the enterprises involved in a merger (Lin et al. 2008; Gaughan 2015). Larger enterprises can gain access to more cost-effective technology or reduce their average costs by distributing them over a larger base. Efficiency can increase also as a result of achieved economies of scale: the transaction may allow the merging parties to enter new markets and to sell their products to a broader range of customers. Finally, consolidation can improve management efficiency. Even if the businesses are too dissimilar to each other to be able to carry out joint activities, they can be sufficiently similar in terms of their strategic goals, customer profiles, and characteristics of the value chain to exchange valuable knowledge (Ficery et al. 2007; Agrawal, Knoeber 2012; Edwards, M. R., Edwards, T. 2013).

By entering into a merger, two enterprises expect from a synergistic effect (that is, the possibility to operate more efficiently) that it will be possible, by joining several businesses, to increase the volume of activities and reduce costs to a greater extent than it would be possible by each of them operating separately. The concept of synergy is usually presented in the following format: " $2+2=5$ ", which means that two enterprises operating jointly create for their shareholders a higher value than they would create if operating separately (Ficery et al. 2007; Lin et al. 2008; Wang, Xie 2009; Brigham, Daves 2012).

Thus, a synergistic effect is usually categorised into:

-Financial synergy, which is manifested through reduced costs of capital of the purchasing enterprise or the enterprise being merged and increased borrowing capacity. A larger enterprise resulting from the merger has better access to a variety of sources of financing, its cash flows usually become stabilised, and risks are reduced;

-Operating synergy which is manifested through income increase and cost reduction. Increase of income is understood as the ability to make use of another enterprise's distribution channels and its customers. Cost reduction is understood as economies of scale that is making better use of the same resources to achieve increased production levels. In this case, it is possible to observe a decline in marginal fixed costs. An enterprise which seeks to acquire another business for the purpose of diversification (splitting) of activities usually acquires an enterprise from a completely unrelated industry, that is, the one having uncorrelated (unrelated to each other) cash flows. While such a splitting of activities is highly risky, because there may be a lack of experience in managing business in another area of activities, but in most cases the risk is justified. Diversification allows to stabilise enterprises' cash flows, because while one enterprise's profitability is declining, the profitability of another enterprise may increase, hence in the long run, downturns in one activity may be offset by upturns in other activities.

M\&As must always correspond to the goal of maximisation of shareholders' benefits, and it is important to compare M\&As against alternatives of internal investment. Therefore, in general terms the following main reasons for these processes may be distinguished (Campbell et al. 2008; Wang, Xie 2009; Parikh 2011; Kotane, KuzminaMerlino 2012; Gaughan 2015):

- Synergistic operating economies- synergistic effect. Operating economies can be achieved by combining activities of two or more enterprises in marketing, procurement, accounting, market share, integration of production lines, and in other areas. In respect of a synergistic effect, it is necessary to determine the value of each of the enterprises separately and then the value of a merged enterprise resulting from restructuring, redundancies, and other changes. Firstly, the balance sheets are simply added together and subsequently adjusted, taking into account the areas where there may be sources of synergies (cost reduction or efficiency increase). The resulting difference is the value of synergistic effect in money terms. When acquiring an enterprise, the purchasing enterprise should not pay a premium that would be in excess of the synergistic effect;

- Increase in size. A merger is for an enterprise the fastest way to grow (as an alternative - to grow through long-term internal investments). In addition, internal growth sometimes has limits due to competitors, the patents held by them, etc.;

- Taxes. Mergers sometimes take place when one of enterprises aims at protecting its profits against taxation;

- Acquisition of new raw materials, equipment, and technology. They are purchased together with the enterprise being purchased;

- Acquisition of financial sources. If the enterprise being purchased is characterised by a large property base and low debt, the purchasing enterprise can expand its borrowing capacity;

- Acquisition of sound management;

- Time savings when entering new markets;

- Diversification. One of the reasons for mergers is activity diversification, which reduces risks;

- Profit growth. A merger allows to quickly show increased profits, as it increases earnings per share. However, over a longer period of time this effect may be lost.

To sum up, it can be claimed that even in the absence of possibilities to achieve any significant synergistic effects, mergers of enterprises will still take place provided that the acquiring enterprise perceives the capacities of the 
enterprise being acquired, the entire economic potential of the businesses being acquired. In this case, upon taking over the control of the enterprises being acquired they are able to manage them much more effectively, to use available resources in the most rational way possible, and to obtain synergistic results.

\section{Factors and process of mergers and acquisitions (M\&As) of enterprises}

The main factor affecting possibilities of the implementation of the M\&As process, regardless of the goals pursued by merging enterprises, is the legal system of the countries in which the enterprises are willing to merger characterised by strict requirements focused on the promotion of competition and antitrust restrictions.

The merger process is affected by various forces which complicate the implementation of set goals of mergers / acquisitions. There are five main factors which make the integration process cumbersome and which also depend on each other and reinforce each other's negative effect (Lin et al. 2006; Chatterjee 2007; Hennephof 2009; Novickyte், Šileika 2010; Adam, Jacob 2012; Agrawal, Knoeber 2012; Deng et al. 2013; Edwards, M. R., Edwards, T. 2013):

- Individual feeling of uncertainty and ambiguity - the situation when following a merger both employees of two enterprises and these enterprises' executives are somewhat confused due to future uncertainty, perceived new opportunities or threats. Therefore, while comprehensively evaluating M\&As, along with financial, legal, strategic, and tactical aspects, it is particularly important to never forget the human factor;

- Organisational policy - corporate mergers can promote changes in the management and organisational hierarchy of the acquired enterprise. Such political activity leads to certain instability for some employees in discovering new opportunities and for others in facing new threats;

- Voluntary withdrawal of key employees - a situation where, due to disagreements with the new management, the inability or unwillingness to adapt to the changed environment and, ultimately, due to certainty as to their chances of finding a new job, the key employees possessing the largest talent and most extensive knowledge and the highest-ranking executives voluntarily withdraw from an enterprise. The loss of such valuable people inevitably has a negative effect on the value of enterprises and possibilities of realising synergies, because the success of acquisitions is, to a large extent, determined by the ability of directors to gain the trust of employees and their support for such investment, and the high quality of employee relations is among the key circumstances facilitating the merger integration process;

- Loss of customers - customers may also perceive a merger as determining future uncertainty, may be worried about the continuity of earlier agreements and contracts or simply unhappy with new procedures and changed corporate policy;

- Cultural resistance occurs when there emerge irreconcilable cultural differences and, consequently, there rise additional problems in implementing integration plans.

The process of M\&As itself may be divided into several stages (Neary 2007; Lin et al. 2008; Baraz, Sakar 2011; Agrawal, Knoeber 2012; Brigham, Daves 2012; Gaughan 2015):

- To conduct research prior to a merger or an acquisition. The situation of an enterprise itself is evaluated and it is determined whether a merger or an acquisition would be the right strategy. If the enterprise expects that in the future it will be difficult for it to maintain quality, market share, return on capital, or other relevant factors, a merger or an acquisition may be the right step. It is important to determine whether the enterprise could achieve its goals through internal development, for example, growth of its market share over the coming years. It is also needed to evaluate one's enterprise as to whether it is adequately estimated (that is, the share price corresponds its actual value);

- To identify the enterprise planned to be acquired, that is, the target of a merger or an acquisition. The target must meet the enterprise's strategic objectives. In this phase, it is also recommended not to use the services of external companies (investment banks), as the search and selection should be carried out as impartially and confidentially as possible;

- To study and evaluate the potential target. The aim is to ascertain that the choice which has been made is really good. In this phase, an evaluation is performed, and the activities of the target and the processes taking place in it are analysed in greater detail. In most cases, it is at this point that an initial in-depth evaluation takes place. Its aim is to consider the potential synergy effect of a merger, the value of an enterprise resulting from the merger. In this phase, the study may be carried out by investment banks;

- To effect a merger or an acquisition through negotiations. Upon selecting and analysing the target, negotiations over a merger or an acquisition can be initiated. It is necessary to evaluate the resistance of the enterprise planned to be acquired, the price bargaining strategy, and the price which could be offered in the first stage of the negotiations;

- Integration following a merger or an acquisition. If everything goes as planned, both enterprises announce about their merger in public and sign a formal contract. Since every enterprise is different, following the merger it is necessary to harmonise operations, internal culture, teams, executives and management levels, information systems, and many other issues. This phase is the most difficult one. Integration can be of 
varying depth, from full (when two enterprises become a single enterprise from all perspectives, taking advantage of the best operating practices of both enterprises) to minimum (when only duplicate staff is reduced, but both enterprises remain decentralised and daily operational decisions are taken separately). If the integration is successful, a synergistic effect should be achieved. However, in reality the perception and success of M\&As is a vague matter.

\section{M\&As market activity}

A corporate M\&As can be seen as an investment. As the Monterrey Consensus emphasised, investment is a powerful catalyst for innovation, economic growth and poverty reduction (Report to the High-Level Development Working Group 2011). Private sector investment is a major source of growth. Foreign investment is a major component of private investment and accounts for a significant share of capital formation, especially in low-income countries (LICs).

It is widely accepted that expansion of private investment, both domestic and foreign, is a main impetus for economic growth. Such as, a number of countries that have had high growth rates through the past two decades have also had consistently higher private investment than countries that did not experience such sustained economic expansion. Greater levels of private investment tend to accompany greater levels of gross domestic product (GDP) growth and development. As domestic private investment remains the principle source of global capital formation, its importance to the growth and development strategy of developing countries is paramount.

In accordance with the United States-European Union High Level Working Group on Jobs and Growth, private sector investment, including domestic and foreign direct private investment, when operated in a responsible manner, can be a key driver of economic development, job creation and inclusive growth (Final Report 2013).

According to Bauer and Matzler (2014) next to strategic alliances and joint ventures, M\&As are an important source of external growth and corporate development.

It is a well-known fact that M\&As come in waves (Golbe, White 1993; Kummer, Steger 2008; Burksaitiene 2010), in which the number of deals swelled, peaked then tumbled. Golbe and White (1993) were among the first to observe empirically the cyclical pattern of M\&As activity. Kummer and Steger (2008) distinguished the six life cycles of M\&As waves:

$$
\begin{aligned}
& \text { 1st-1887-1907; } \\
& \text { 2nd-1919-1933; } \\
& \text { 3rd-1955-1975; } \\
& \text { 4th-1980-1989; } \\
& \text { 5th-1992-2002; } \\
& \text { 6th-2003-2007. }
\end{aligned}
$$

After the 2008-2009 global economic-financial crisis began economic stagnation which provoked at least for some countries new waves of M\&As.

In accordance with Trade and Development Report (2016), in 2016 global output is likely to decelerate moderately to a growth rate around $2.3 \%$, compared with $2.5 \% 2015$. This is the sixth year in a row that the global economy repeats a modest expansion, well below that of pre-crisis levels. This year's performance reflects an expected slowdown in developed countries growth, from 2 to $1.6 \%$; economic stagnation in transition economies, an improvement over their contraction in 2015; and the continuing growth in developing countries of about 4\%, resulting from sustained growth in most Asian countries, a deceleration in Africa and economic recession in Latin America and the Caribbean.

The growth of global merchandise trade volume slowed to $1.5 \%$ in 2015 , from $2.3 \%$ in 2014 , and the slow pace has continued through the first half of 2016. This trend, which began in 2012, has been more pronounced than for world output.

The further research of this paper authors results have proved that the growth of cross-border M\&As was provoked by the expansion of the European Union and by consequently changing terms of international trade.

\section{Correlation of GDP growth and the dynamics of value of cross-border M\&As of countries EU members from 2004}

Logic suggests that gross domestic product (GDP) growth pattern directly influences the dynamics of cross-border M\&As. Change of former command economies to free market system and further entrance to European Union (EU) should have impact also. So, authors had formulated the first hypothesis that the next year after becoming the member of EU a wave of cross-border M\&As (sales) should rise.

The second hypothesis is that the dynamics of the GDP (Table 2) should correlate with that of value of crossborder M\&As of analysed countries (Table 3). 
Table 2. GDP at market prices (current prices, million euro)

of countries EU members from 2004, years 2005-2015

(Source: prepared by the authors, according to Eurostat data 2016)

\begin{tabular}{l|c|c|c|c|c|c|c|c|c|c|c}
\hline Country/Year & 2005 & 2006 & 2007 & 2008 & 2009 & 2010 & 2011 & 2012 & 2013 & 2014 & 2015 \\
\hline Czech Republic & 109394 & 123743 & 138004 & 160962 & 148357 & 156370 & 164041 & 161434 & 157742 & 156660 & 166964 \\
Estonia & 11262 & 13522 & 16246 & 16517 & 14146 & 14717 & 16668 & 17935 & 18890 & 19758 & 20252 \\
Cyprus & 15039 & 16264 & 17591 & 19006 & 18674 & 19300 & 19731 & 19467 & 18118 & 17567 & 17637 \\
Latvia & 13726 & 17264 & 22679 & 24355 & 18749 & 17789 & 20169 & 22021 & 22816 & 23608 & 24349 \\
Lithuania & 21002 & 24079 & 29041 & 32696 & 26935 & 28028 & 31275 & 33348 & 35002 & 36590 & 37331 \\
Hungary & 90590 & 91399 & 101692 & 107637 & 93809 & 98323 & 100820 & 99086 & 101483 & 104953 & 109674 \\
Malta & 5142 & 5386 & 5758 & 6129 & 6139 & 6600 & 6835 & 7161 & 7631 & 8426 & 9250 \\
Poland & 246201 & 274603 & 313874 & 366182 & 317083 & 361804 & 380239 & 389369 & 394721 & 410990 & 429794 \\
Slovenia & 29235 & 31561 & 35153 & 37951 & 36166 & 36252 & 36896 & 36003 & 35917 & 37332 & 38570 \\
Slovakia & 39348 & 45530 & 56242 & 66003 & 64023 & 67577 & 70627 & 72704 & 74170 & 75946 & 78686 \\
\hline
\end{tabular}

The third hypothesis is: isolated decisions to merge or acquire large scale companies may have impact on the dynamics of value of cross-border M\&As of analysed countries.

For the analysis of these hypothesis graphical and correlation analysis was chosen.

Table 3. Value of cross-border M\&As, by economy of seller (net sales, current prices, million euro) of countries EU members from 2004, years 2005-2015

(Source: prepared by the authors, according to UNCTAD data 2016)

\begin{tabular}{l|c|c|c|c|c|c|c|c|c|c|c}
\hline Net sales & 2005 & 2006 & 2007 & 2008 & 2009 & 2010 & 2011 & 2012 & 2013 & 2014 & 2015 \\
\hline Czech Republic & 7708 & 1449 & 337 & 406 & 3449 & -703 & 1009 & 48 & 2148 & 4266 & 2503 \\
Estonia & 102 & 4 & -81 & 162 & 39 & 4 & 333 & 75 & -105 & 31 & -42 \\
Cyprus & 30 & 369 & 1783 & 1194 & 66 & 919 & 1089 & 66 & 1882 & 1654 & 120 \\
Latvia & 11 & 14 & 64 & 287 & 152 & 72 & 1 & 1 & 5 & 65 & 204 \\
Lithuania & 76 & 122 & 48 & 253 & 32 & 623 & 537 & 50 & 40 & 105 & 30 \\
Hungary & 3073 & 2934 & 2834 & 2542 & 2585 & 296 & 2386 & 123 & -1470 & -379 & 40 \\
Malta & 15 & 649 & -118 & 0 & 18 & 418 & 0 & 123 & 9 & 295 & 17 \\
Poland & 1850 & 971 & 932 & 2216 & 929 & 1584 & 13868 & 1059 & 534 & 1242 & 1428 \\
Slovenia & 184 & 19 & 78 & 615 & 0 & 440 & 71 & 424 & 40 & 658 & 181 \\
Slovakia & 146 & 244 & 90 & 200 & 29 & 0 & 0 & 162 & 719 & -1 & 1113 \\
Total & 13195 & 6775 & 5967 & 7875 & 7299 & 3653 & 19294 & 2131 & 3802 & 7936 & 5594 \\
\hline
\end{tabular}

In 2013-2015, the most active economic sectors in the Baltic M\&As market were Construction and Real Estate, Services, Technology, Financial Services, and Energy and Utilities. Although transaction values vary greatly, the value of most typical Baltic M\&As transaction remains in the EUR 1-5 million bracket (Baltic M\&A Deal Points Study 2016). Data about the net sales of cross-border M\&As (Table 3) is lower but does not contradict the total sales data presented in Baltic M\&A Deal Points Study (2016).

Graph of Value of cross-border M\&As, by economy of seller (net sales, current prices, million euro) of countries European Union members from 2004, years 2005-2015 (Fig. 1) allows to come to the two conclusions: the first one: this indicator is changing cyclically. 
Burksaitiene, D.; Garskaite-Milvydiene, K. 2017. Cross-border mergers and acquisitions factors in joining the European Union countries

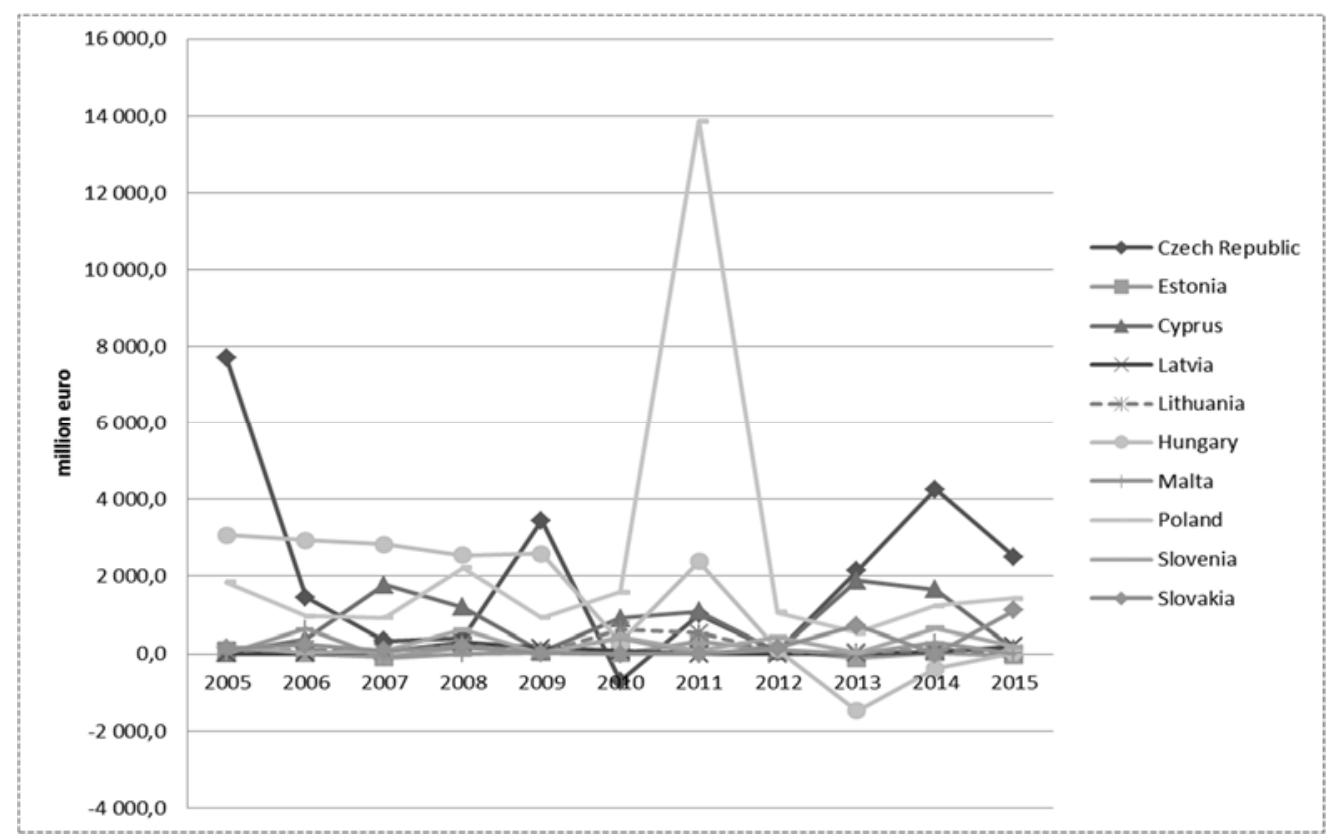

Fig. 1. Value of cross-border M\&As, by economy of seller (net sales, current prices, million euro) of countries EU members from 2004, years 2005-2015 (Source: prepared by the authors)

The second conclusion is: sometimes happen huge waves of cross-border M\&As in separate countries. These waves do not allow compare cyclical components of value of cross-border M\&As in separate countries. Much easier is analyse the cyclicality of this process using value of cross-border M\&As, by economy of seller, presented as percent of GDP of countries European Union members from 2004, years 2005-2015 (Table 4).

Table 4. Value of cross-border M\&As, by economy of seller (as percent of GDP) of countries EU members from 2004, years 2005-2015

(Source: prepared by the authors, according to UNCTAD data 2016)

\begin{tabular}{c|c|c|c|c|c|c|c|c|c|c|c}
\hline Net sales & 2005 & 2006 & 2007 & 2008 & 2009 & 2010 & 2011 & 2012 & 2013 & 2014 & 2015 \\
\hline Czech Republic & 7.05 & 1.17 & 0.24 & 0.25 & 2.33 & 0.45 & 0.62 & 0.03 & 1.36 & 2.72 & 1.50 \\
Estonia & 0.91 & 0.03 & -0.50 & 0.98 & 0.28 & 0.03 & 2.00 & 0.42 & -0.56 & 0.15 & -0.21 \\
Cyprus & 0.20 & 2.27 & 10.14 & 6.28 & 0.35 & 4.76 & 5.52 & 0.34 & 10.39 & 9.42 & 0.68 \\
Latvia & 0.08 & 0.08 & 0.28 & 1.18 & 0.81 & 0.40 & 0.01 & 0.01 & 0.02 & 0.28 & 0.84 \\
Lithuania & 0.36 & 0.51 & 0.17 & 0.77 & 0.12 & 2.22 & 1.72 & 0.15 & 0.11 & 0.29 & 0.08 \\
Hungary & 3.39 & 3.21 & 2.79 & 2.36 & 2.76 & 0.30 & 2.37 & 0.12 & -1.45 & -0.36 & 0.04 \\
Malta & 0.29 & 12.05 & -2.05 & 0.00 & 0.30 & 6.33 & 0.00 & 1.72 & 0.12 & 3.50 & 0.18 \\
Poland & 0.75 & 0.35 & 0.30 & 0.61 & 0.29 & 0.44 & 3.65 & 0.27 & 0.14 & 0.30 & 0.33 \\
Slovenia & 0.63 & 0.06 & 0.22 & 1.62 & 0.00 & 1.21 & 0.19 & 1.18 & 0.11 & 1.76 & 0.47 \\
Slovakia & 0.37 & 0.53 & 0.16 & 0.30 & 0.05 & 0.00 & 0.00 & 0.22 & 0.97 & 0.00 & 1.41 \\
Average & 1.40 & 2.03 & 1.18 & 1.44 & 0.73 & 1.52 & 1.61 & 0.45 & 1.12 & 1.81 & 0.53 \\
\hline
\end{tabular}

Graphical analysis of value of cross-border M\&As, by economy of seller as percent of GDP (Fig. 2) revealed that two former offshore countries Malta and Cyprus are leaders in cross-border M\&As with a peak for Malta in 2006 and three peaks for Cyprus in 2007, 2013 and 2014. Due to Malta's and Cyprus joining the EU these two countries have had to restructure their international financial sector according to EU legislation and offshore sector was affected by deep restructuring. Nevertheless, Malta and Cyprus have had preserved their relative competitive advantage in cross-border M\&As in terms of a percent of GDP (Fig. 2).

In such a case, (Fig. 2) with nonlinear dynamics, Pearson linear correlation analysis will give misleading results. Spearman's rank correlation analysis suits much better, because it allows finding out correlation between waves of the analysed two data sets. 


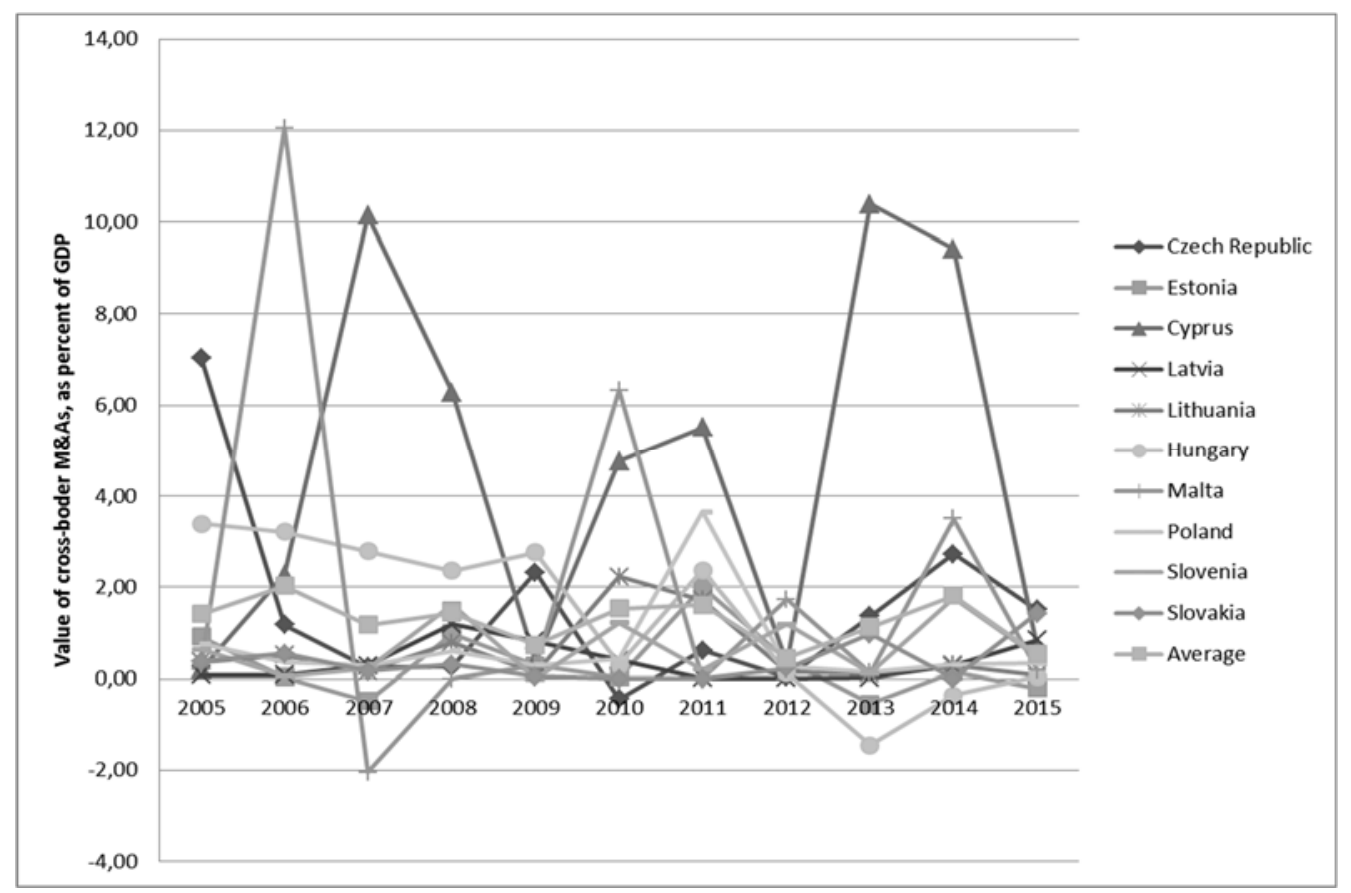

Fig. 2. Value of cross-border M\&As by economy of seller as a percent of GDP of countries EU members from 2004, years 2005-2015 (Source: prepared by the authors)

The biggest peaks in Figure 2 are presented by special cases of Cyprus and Malta which masks situation of value of cross-border M\&As by economy of seller as a percent of GDP in other "normal" countries. In Figure 3 situation with these "normal" countries is presented.

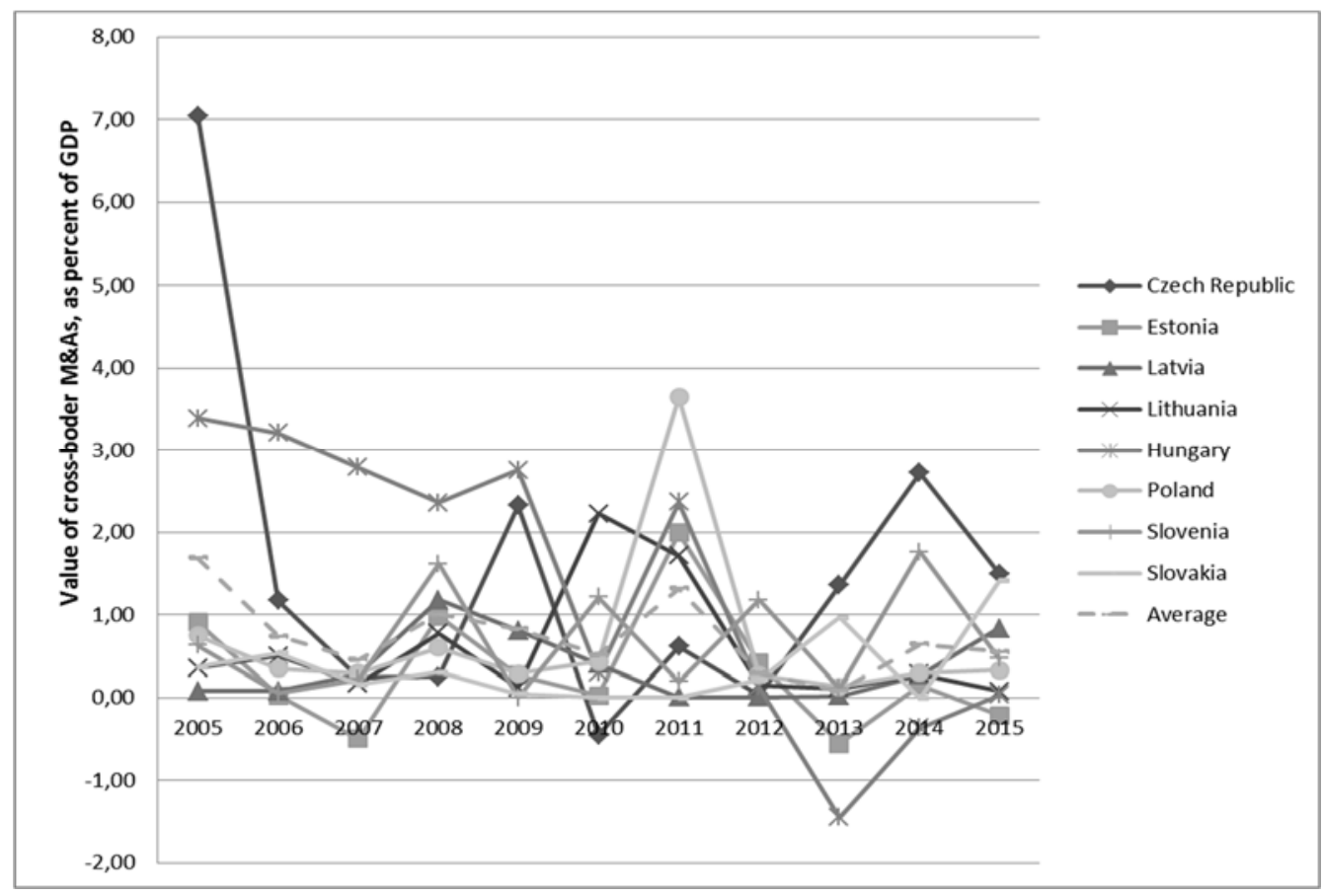

Fig. 3. Value of cross-border M\&As by economy of seller as percent of GDP of countries EU members from 2004 (excluding Cyprus and Malta), years 2005-2015 (Source: prepared by the authors)

As it was mentioned above, Figures 2 and 3 show that correlation of value of cross-border M\&As by economy of seller as a percent of GDP of countries European Union members from 2004 (years 2005-2015) is not linear, so Pearson correlation coefficient is not applicable. In such situations Spearman coefficient of rank correlation $r_{s}$ is preferred. The results of Spearman coefficient of rank correlation analysis are presented in Table 5. 
Table 5. Spearman coefficient of rank correlation $r_{s}$ of GDP relation with cross-border M\&As, by economy of seller, of countries EU members from 2004, years 2005-2015 (Source: prepared by the authors)

\begin{tabular}{|c|c|c|c|c|c|c|c|c|c|c|c|c|c|c|c|c|c|c|c|c|c|c|}
\hline$\stackrel{\vec{\Xi}}{\vec{\nu}}$ & 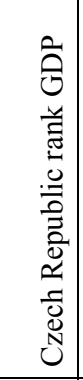 & 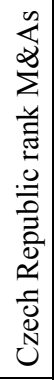 & 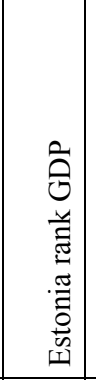 & 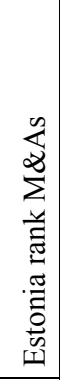 & 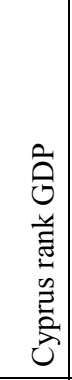 & 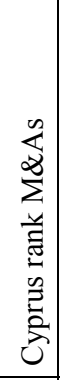 & 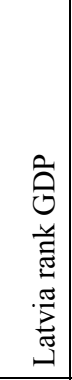 & 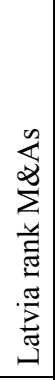 & 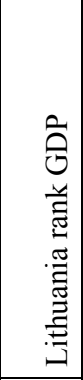 & 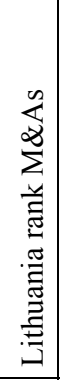 & 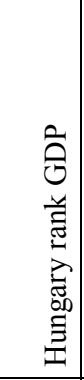 & 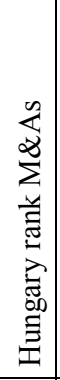 & 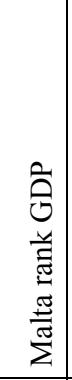 & 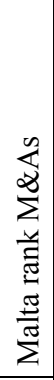 & 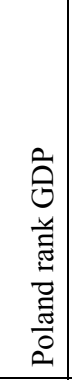 & 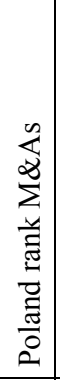 & 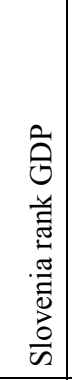 & 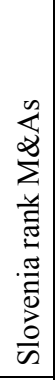 & 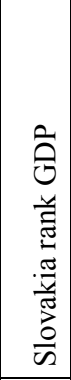 & 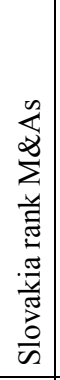 & 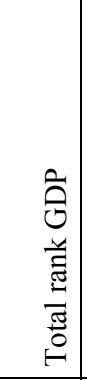 & 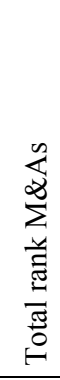 \\
\hline 2005 & 32 & 1 & 11 & 3 & 11 & 11 & 11 & 8 & 11 & 6 & 11 & 1 & 11 & 7 & 11 & 3 & 11 & 5 & 11 & 6 & 11 & 2 \\
\hline 2006 & 29 & 6 & 10 & 8 & 10 & 7 & 10 & 7 & 10 & 4 & 10 & 2 & 10 & 1 & 10 & 8 & 10 & 10 & 10 & 3 & 10 & 6 \\
\hline 2007 & 27 & 9 & 7 & 10 & 8 & 2 & 5 & 6 & 7 & 8 & 4 & 3 & 9 & 11 & 9 & 9 & 9 & 7 & 9 & 7 & 9 & 7 \\
\hline 2008 & 17 & 8 & 6 & 2 & 4 & 4 & 1 & 1 & 5 & 3 & 2 & 5 & 8 & 10 & 6 & 2 & 2 & 2 & 7 & 4 & 6 & 4 \\
\hline 2009 & 25 & 3 & 9 & 5 & 5 & 9 & 8 & 3 & 9 & 10 & 9 & 4 & 7 & 5 & 8 & 10 & 6 & 11 & 8 & 8 & 8 & 5 \\
\hline 2010 & 23 & 11 & 8 & 7 & 3 & 6 & 9 & 4 & 8 & 1 & 8 & 7 & 6 & 2 & 7 & 4 & 5 & 3 & 6 & 10 & 7 & 10 \\
\hline 2011 & 13 & 7 & 5 & 1 & 1 & 5 & 7 & 10 & 6 & 2 & 6 & 6 & 5 & 9 & 5 & 1 & 4 & 8 & 5 & 9 & 5 & 1 \\
\hline 2012 & 15 & 10 & 4 & 4 & 2 & 10 & 6 & 11 & 4 & 7 & 7 & 8 & 4 & 4 & 4 & 7 & 7 & 4 & 4 & 5 & 4 & 11 \\
\hline 2013 & 19 & 5 & 3 & 11 & 6 & 1 & 4 & 9 & 3 & 9 & 5 & 11 & 3 & 8 & 3 & 11 & 8 & 9 & 3 & 2 & 3 & 9 \\
\hline 2014 & 21 & 2 & 2 & 6 & 9 & 3 & 3 & 5 & 2 & 5 & 3 & 10 & 2 & 3 & 2 & 6 & 3 & 1 & 2 & 11 & 2 & 3 \\
\hline 2015 & 11 & 4 & 1 & 9 & 7 & 8 & 2 & 2 & 1 & 11 & 1 & 9 & 1 & 6 & 1 & 5 & 1 & 6 & 1 & 1 & 1 & 8 \\
\hline$r_{s}$ & -0.25 & & -0.23 & & 0.04 & & 0.40 & & -0.30 & & -0.59 & & 0.13 & & 0.01 & & 0.44 & & 0.08 & & -0.25 & \\
\hline
\end{tabular}

As Table 5 shows, Spearman coefficient of rank correlation $r_{s}$ of GDP relation with cross-border M\&As, by economy of seller, of countries European Union members from 2004 (years 2005-2015) varies from -0.59 to 0.01.

When the degree of freedom is 11 (Table 5), the Spearman correlation coefficient has to be more than 0.6 for the hypothesis to be more than $95 \%$ reliable. This means, that the influence of GDP dynamics to value of crossborder M\&As by economy of seller is not proved for the analysed countries with the necessary degree of reliability.

But peaks do exist. One of them is after one year of joining the European Union, in 2005, when the total crossborder M\&As were one of the largest in the period of 2005-2015. The biggest volumes of cross-border M\&As in total for the analysed countries was $19.3 \mathrm{bln}$. euro in 2011, with the $13.9 \mathrm{bln}$. euro cross-border M\&As in Poland only (Table 3).

\section{Conclusions}

In this paper the theoretical analysis performed has demonstrated that the main goals pursued by M\&As of enterprises include the increase or maintenance of existing market share and expansion of geographical market share, acquisition of new services and products, economies of scale, corporate growth, taking advantage of a sound transaction, and diversification.

The development of the M\&As market is driven by the following causes: facilitated trade and globalisation, privatisation and decrease of legal constraints, technological progress, the pursuit of economies of scale, industry volatility, rise of share prices, decrease of interest rates, and strong economic growth. These factors lead to intensification of competition, increase in the number of its forms of manifestation, acceleration of the introduction of products, and shortening of the product life cycle. Distribution channels are changing, while boundaries between industries are becoming increasingly blurred.

It is absolutely necessary to analyse the historical experience of similar economic entities, to develop a clear and unambiguous definition of the key objectives of prospective transactions, and to consolidate the foundations for their realisation by analysing integration preconditions and risks and assessing potential social, emotional, and other employment relationship-related consequences of M\&As for employees of both enterprises. It is necessary to ensure full understanding of the culture and organisational policy of the enterprise being taken over and to provide for a transitional period for the successful integration of the personnel, tasks and procedures along with the reorganisation of the management system and the restructuring of the enterprises' operations.

Empirical analysis of factors, influencing cross-border M\&As (sales) revealed that the next year after becoming member of EU wave of cross-border M\&As (sales) is rising. After one year of joining the European Union, in 2005, the total cross-border M\&As sales were the largest in the period of 2005-2015 (Table 4 line "average"). 
The dynamics of the GDP should is not correlated with that of value of cross-border M\&As of analysed countries what is not confirmed by the Spearman coefficient of rank correlation $r_{s}$ analysis of this factor. Spearman coefficient of rank correlation $r_{s}$ for GDP relation to cross-border M\&As in all countries varied from 0.04 to - 0.59, what means, that in all analysed countries this correlation is not significant.

The dynamics of value of cross-border M\&As of analysed countries may be impacted by isolated decision to merge or acquire large scale companies is separate countries. As it may be observed from the case of Poland in 2011 - 14 bln. euro and Czech Republic in 2005 - 8 bln. euro of cross-border M\&As sales, these events had very significant influence to the total dynamics of cross-border M\&As sales for the analyse group of EU countries.

\section{References}

Adam, A.; Jacob, S. E. 2012. Consequences and possible solutions of financial crisis, Theoretical and Applied Economics 12(577): 143-148.

Agrawal, A.; Knoeber, Ch. R. 2012. Corporate governance and firm performance, Chapter 26, in R. T. Christopher; W. F. Shughart (Eds.). Managerial economics. New York, NY: Oxford University Press.

Baltic M\&A Deal Points Study [online], 2016 [cited 19 January 2017]. Available from Internet: http://vca.lt/wp-content/uploads/2016/05/Baltic-MA-Deal-Points-Study-2016.pdf

Baraz, B.; Sakar, A. N. 2011. Organization design and innovation: a comparative analysis of two corporations, International Journal of Business and Management Studies 3(1): 67-79.

Bauer, F.; Matzler, K. 2014. Antecedents of M\&A success: the role of strategic complementarity, cultural fit, and degree and speed of integration, Strategic Management Journal 35(2): 269-291. https://doi.org/10.1002/smj.2091

Bevins, V.; Feeney, P.; Jones, C. 2010. Mergers and acquisitions data 2000-2009 [online], The Financial Times [cited 10 September 2016]. Available from Internet: http:/www.ft.eom/cms/s/2/6cba359a-31ce-11df-9ef500144feabdc0,dwp_uuid=aece9792-aa13-11da-96ea-0000779e2340.html

Brigham, E. F.; Daves, P. R. 2012. Intermediate Financial Management. $11^{\text {th }}$ ed. Mason, OH: South-Western Cengage Learning.

Burkart, W. R.; Klein, R.; Mayer, S. 2012. Product line pricing for services with capacity constraints and dynamic substitution, European Journal of Operational Research 219(2): 347-359. https://doi.org/10.1016/j.ejor.2011.12.026

Burksaitiene, D. 2010. Cross-border mergers and acquisitions: an analysis of activity, in $6^{\text {th }}$ International Scientific Conference “Business and Management 2010”, Selected papers, 13-14 May 2010, Vilnius, Lithuania. 1: 30-37. https://doi.org/10.3846/bm.2010.005

Campbell, J. Y.; Hilscher, J.; Szilagyj, J. 2008. In search of distress risk, Journal of Finance 63: 2899-2939. https://doi.org/10.1111/j.1540-6261.2008.01416.x

Chatterjee, S. 2007. Why is synergy so difficult in mergers of related businesses? Strategy \& Leadership 35(2): 46-52. https://doi.org/10.1108/10878570710734534

Cornett, M. M.; McNutt, J. J.; Tehranian, H. 2006. Performance changes around bank mergers: revenue enhancements versus cost reductions, Journal of Money, Credit and Banking 38(4): 1013-1050. https://doi.org/10.1353/mcb.2006.0053

Cullen, J. B.; Praveen, P. K. 2011. Multinational management: a strategic approach. $5^{\text {th }}$ ed. Mason: Thomson South-Western.

Deng, X.; Kang, J. K.; Low, B. S. 2013. Corporate social responsibility and stakeholder value maximization: evidence from mergers, Journal of Financial Economics 110(1): 87-109. https://doi.org/10.1016/j.jfineco.2013.04.014

DePamphilis, D. M. 2010. Mergers, acquisitions, and other restructuring activities. Burlington: Academic Press.

Edwards, M. R.; Edwards, T. 2013. Employee responses to changing aspects of the employer brand following a multinational acquisition: a longitudinal study, Human Resource Management 52: 27-54. https://doi.org/10.1002/hrm.21519

Eurostat [online], 2016 [cited 19 January 2017]. Available from Internet: http://ec.europa.eu/eurostat

Ficery, K.; Herd, T.; Pursche, B. 2007. Where has all the synergy gone? The M\&A Puzzle, Journal of Business Strategy 28(5): 29-35. https://doi.org/10.1108/02756660710820802

Final Report. 2013. High level working group on jobs and growth [online], [cited 19 January 2017]. Available from Internet: http://trade.ec.europa.eu/doclib/docs/2013/february/tradoc_150519.pdf

Fraser, D. R; Zhang, H. 2009. Mergers and long-term corporate performance: evidence from cross-border bank acquisitions, Journal of Money, Credit and Banking 41(7): 1503-1513. https://doi.org/10.1111/j.1538-4616.2009.00265.x

Garskaite-Milvydiene, K.; Burksaitiene, D. 2016. Pecularities of bankruptcies, restructuring, mergers and acquisitions in Lithuania in the post-crisis period, Inzinerine Ekonomika-Engineering Economics 27(5): 546-556.

Gaughan, P. A. 2015. Mergers, acquisitions, and corporate restructurings. $6^{\text {th }}$ ed. Hoboken, N. J.: John Wiley \& Sons.

Ginevičius, R.; Bivainis, J.; Melnikas, B.; Paliulis, N.; Rutkauskas, A. V.; Staškevičius, A. J.; Pabedinskaitė, A.; Šečkutė, L.; Tamošiūnas, A. 2005. Šiuolaikinis verslas: tobulinimo prioritetai: monografija. Vilnius: Technika.

Golbe, D. L.; White, L. J. 1993. Catch a wave: the time series behaviour of mergers, The Review of Economics and Statistics 75(3): 493-499. https://doi.org/10.2307/2109463. Available from Internet: http://www.jstor.org/stable/2109463

Gruodis, P. 2009. The Mergers and acquisitions review. Chapter 36 - Lithuania, 343-350 [online], [cited 10 September 2016]. Available from Internet: http://www.glimstedt.lt/files/publication_pdf/publication_41.pdf

Hennephof, B. 2009. Mergers and Acquisitions Explained [online], [cited 10 September 2016]. Available from Internet: http://www.m-and-a-explained.com 
Kotane, I.; Kuzmina-Merlino, I. 2012. Assessment of financial indicators for evaluation of business performance, European Integration Studies 6: 216-224. https://doi.org/10.5755/j01.eis.0.6.1554

Kummer, C.; Steger, U. 2008. Why merger and acquisition (M\&A) waves reoccur: the vicious circle from pressure to failure, Strategic Management Review 2(1): 44-63.

Lietuvos Respublikos akciniu bendroviu istatymas [Joint-stock Company Law of the Republic of Lithuania]. 1994. Valstybès žinios [State News]. Nr. 55-1046 [online], [cited 20 January 2017]. Available from Internet: https://e-seimas.lrs.lt/portal/legalAct/lt/TAD/TAIS.19881/eQHQKWebkV

Lin, B. W.; Hung, S. C.; Li, P. C. 2006. Mergers and acquisitions as a human resource strategy: evidence from US banking firms, International Journal of Manpower 27(2): 126-142. https://doi.org/10.1108/01437720610666173

Lin, B.; Lee, Z.; Gibbs, L. G. 2008. Operational restructuring: reviving an ailing business, Management Decision 46(4): 539-552. https://doi.org/10.1108/00251740810865049

MacNab, B. R.; Worthley, R. 2013. Stereotype awareness development and effective cross-cultural management - an experimental approach, International Journal of Cross Cultural Management 13(1): 67-87. https://doi.org/10.1177/1470595812452635

Milichovsky, F.; Simberova, I. 2015. Marketing effectiveness: metrics for effective strategic marketing, Journal of Engineering Economics 26(2): 211-219. https://doi.org/10.5755/j01.ee.26.2.3826

Neary, J. P. 2007. Cross-border mergers as instruments of comparative advantage, Review of Economic Studies 74(4): 1229-1257. https://doi.org/10.1111/j.1467-937X.2007.00466.x

Novickyte, L.; Šileika, T. 2010. Imonių susiliejimų ir įsigijimų teoriniai ir praktiniai aspektai, Journal of Business Management and Education [online], [cited 10 September 2016]. Available from Internet: http://leidykla.vgtu.lt/conferences/BME_2010/001/pdf/Art-Novickyte-Sileika.pdf

Parikh, V. 2011. Reasons for corporate restructuring [online], [cited 10 September 2016]. Available from Internet: $\mathrm{http} / / / \mathrm{www}$.letslearnfinance.com/reasons-for-corporate-restructuring.html

Report to the High-Level Development Working Group [online], 2011 [cited 19 January 2017]. Available from Internet: http://www.euintheus.org/what-we-do/policy-areas/trade-investment-and-business/high-level-working-group-on-jobs-andgrowth/

Roman, A.; Rusu, V. D. 2011. Effects of the current economic crisis on small and medium enterprises sector in some EU member countries - a comparative study, International Journal of Business and Management Studies 3(1): 333-342.

Stankeviciene, J.; Sviderske, T.; Miecinskiene, A. 2014. Dependence of sustainability on country risk indicators in EU Baltic Sea region countries, Journal of Business Economics and Management 15(4): 646-663. https://doi.org/10.3846/16111699.2014.965555

Trade and Development Report [online], 2016 [cited 19 January 2017]. Available from Internet: http://unctad.org/en/PublicationsLibrary/tdr2016_en.pdf

Ulrich, W. 2012a. Operational research and critical systems thinking - an integrated perspective Part 1: OR as applied systems thinking, Journal of the Operational Research Society 63(9): 1228-1247. https://doi.org/10.1057/jors.2011.141

Ulrich, W. 2012b. Operational research and critical systems thinking - an integrated perspective Part 2: OR as argumentative practice, Journal of the Operational Research Society 63(9): 1307-1322. https://doi.org/10.1057/jors.2011.145

UNCTAD [online], 2016 [cited 19 January 2017]. Available from Internet: http://unctad.org/en/Pages/Home.aspx

Wang, C.; Xie, F. 2009. Corporate governance transfer and synergistic gains from mergers and acquisitions, The Review of Financial Studies 22(2): 829-858. https://doi.org/10.1093/rfs/hhn018 